\title{
Influence of Athletic Training With Pair Jump Rope Training Model and Ladder Drill to Increase Ability Kids Athletic Elementary School Students
}

\author{
Ujang Rohman ${ }^{1 *}$, Abd. Cholid ${ }^{2}$, Regina Septiria ${ }^{3}$, and Arif Luqman Hakim ${ }^{4}$ \\ ${ }^{I}$ Faculty of Teacher Training and Education, University of PGRI Adi Buana Surabaya, Surabaya, Indonesia, \\ 2,3,4 Graduate Program, University of PGRI Adi Buana Surabaya, Surabaya, Indonesia, abdcholid@unipasby.ac.id \\ *Corresponding author. Email: ujang_roh64@unipasby.ac.id
}

\begin{abstract}
This research aims to develop varied athletic sports learning through athletic training in pair jump rope and ladder drill models to improve abilities (kids athletic elementary school students. The research method uses an experimental method with a quantitative approach. Randomized Group Preetest-Posttest Design Research Design. The population was Sawahan IV Surabaya Elementary School students, while the sample of class IV and V students selected by stratified proportional sampling was 32 people divided into two groups, each given a paired jump rope model (X1) and a ladder drill model (X2). Data collection using the IAAF Kids Athletics Test data were analyzed using statistical analysis of the $t$ test and anava at the level of sig $\alpha=0.05$ Results of analysis $>t$ Sig. 0.05 meant that athletic training in the paired jump rope model and the ladder drill model could increase the ability of kids athletic students Das School ar. While the results of the analysis of variants of the athletic kids element test obtained > F sig. 0.05 means that there is a significant difference between the athletic training of the pair jump rope model and the ladder drill model in improving the ability of kids athletic elementary school students.
\end{abstract}

Keywords: pair jump, ladder drill, kids athletic

\section{INTRODUCTION}

Athletics is one of the learning materials of Physical Education in Sport and Health (PJOK) taught in schools starting at the Elementary School level (SD) to High School Level (SLTA). Athletic learning that has been introduced since elementary school age will directly affect motor skills (locomotor, non-locomotor and manipulative) that are needed in the development and growth of children. Motor is everything that has to do with gestures. To develop motor skills, there are three elements that determine the muscles, nerves and brain. According to Samsudin, (2008), the three motor elements carry out each of their roles in positive interactions, meaning that one element is interrelated, mutually supporting, complementing each other to achieve a more perfect motor condition. The occurrence of motor development in children is a reflection of changes in the individual when interacting with the environment involving the muscles in the body in a coordinated manner through motion activities.

Children's motor development will develop if in the learning process PJOK at school is given a variety of learning by implementing and developing learning models that are both creative and innovative. PJOK learning materials that apply such learning include athletic sports subjects. The material for athletic sports in schools that have been developed and applied to children at the elementary school level are currently an athletic sports program for children called kids athletics. According to Rumini (2014), kids' athletics is one of the games created by physical education experts to stimulate children or motivate children to move to resemble real athletic learning. Meanwhile, according to Huang (2012), the goal of kids athletics is to introduce athletic sports early or since children are still small, so that athletics is a fun gesture and will be the experience of someone who is brought to adulthood. Currently kids athletics have spread to schools throughout Indonesia, and even have competed in POPDA events at the subdistrict, district and provincial levels. When viewed from the characteristics of the movements of kids athletics have the basic elements of motion to run, jump and throw, therefore the development of the abilities of kids athletics children must go through a physical exercise approach that has characteristics in the form of basic motions to run, jump and throw.

Athletic training models to develop the abilities of these athletic kids include the paired jump rope model in the form of vertical jump and the jump ladder drill model in the form of horizontal jump. Jump rope is a game that uses a rope-like tool composed of rubber 
band material, this game is very simple and useful as a means of playing as well as sports. Paired jump rope is an item for playing or physical training consisting of a rope made of braided rubber bands or synthetic material with a handle attached to each child in pairs by rotating the rope, then the child jumps between the ropes in a continuous rhythm - without stopping. The effects caused by playing jump rope in pairs according to [2] research results can train the strength of leg muscles, flexibility, agility and balance of children, and can increase children's confidence. In addition, Harsono in [3], revealed that to improve children's gross motor development can be done through jump rope games in pairs. Jump rope game can affect the gross motor skills in children [4]. Referring to this opinion, it can be concluded that the pair jumping rope which is done by jumping over the obstacle in the form of a rope aims to improve the child's gross motor skills, leg muscle work, flexibility and balance of the body and coordination of eyes, arms and legs.

Other forms of exercise to develop children's athletic sports in addition to the pair jump rope model are the ladder model or the ladder drill model. Ladder drill training is essentially like a ladder, which is an excellent form of athletic training to improve overall foot speed, coordination and agility. According to Pratama, Mintarto and Kusnanik (2018), ladder drills exercise has a significant effect on speed and agility because the leg muscles constantly perform contractions continuously during the exercise. Ladder drill exercises are used to develop leg speed, when performing various ways of jumping and also to increase leg muscle power. Ladder drill training is a tool to train the speed and agility in the form of a ladder that is placed on the surface of the ground or the field serves to train leg muscles [5]. Ladder drill is the most common ladder exercise used to help children train speed and agility through coordinating the foot in the horizontal direction of the stairs.

Referring to the concept of the pair jump rope and ladder drill model, it can be concluded that the pair jump rope training model can be used to train the work of leg muscles, flexibility and balance of the body and coordination of eyes, arms and legs. While the ladder drill model exercises can be used to train to develop leg speed in various jumps and also to train to develop leg muscle power. Both of these exercise models have similarities in developing motor skills, namely developing functional coordination between the muscular, nervous and brain systems that produce motor functions such as walking, running and jumping. Based on the description above and the results of researchers' observations through observations made when athletic learning in elementary school data obtained that the process of athletic learning in elementary schools has not run optimally, because the learning media used is too monotonous so that it is less varied and innovative which causes students to lack motivation and trust yourself in following learning. Referring to this, the researchers tried to develop interesting and varied basic sports learning of athletic sports through athletic training in the model of jump rope pairs and drills with the aim of increasing the ability of kids athletic students who are guided by the techniques and principles of training. Because in this research, there will be an examination of athletic training in the pair jump rope model and the ladder drill model as an athletic training media to develop and improve the abilities of kids athletics. Problems in this study include; (1) on the effect of athletic training in pairing and ladder drill jump rope models on improving the ability of athletic kids and (2) on the difference in the effect of athletic training in paired jump rope models with ladder drill exercises on improving the ability of kids athletic elementary school students. While the research objective is to find out and develop athletic training in pair jump rope models and ladder drill effects on improving the abilities of kids athletics, as well as prove whether there are differences in athletic training in pair jump rope models with ladder drill models to improve the abilities of kids athletic elementary school students. The urgency of the results of this study is expected to be a reference and recommendation for PJOK teachers that athletic training in paired jump rope and ladder drill models can be used as an alternative material and media for athletic training in improving the ability of athletic kids students in elementary schools consisting of running components (canga's escape and formula one), jump (frog jump) and throw (turbo throwing). Besides that, with the increase in the ability of kids athletic students, it is expected that athletic sports will be increasingly favored by children in elementary schools and many new seeds are found in athletics.

\section{METHOD}

The method used in this research is the experimental method. This type of research is a field experiment where the principles of replication, randomization and treatment are all met (Sugiono, 2013). The study design uses the Randomized Group Pretest-Postest Design design which is described as follows:

K1 $=$ Preetest: -------------- Postest
K2 $=$ Preetest: --------------- Postest


Variables consist of independent variables (X) and bound $(\mathrm{Y})$. The independent variable was athletic training in the pair jump rope model (X1) and the ladder drills model (X2), while the dependent variable was the ability of Kid's athletics (Y).

The population is the whole subject of research (Arikunto, 2010). The study population was students at Sawahan IV Public Elementary School, Sawahan District, Surabaya City. While the research sample is part or representative of the population under study (Arikunto, 2010). The sample is male students of class IV and V of Sawahan IV Primary School, Sawahan District, Surabaya City. The sampling technique in proportion based on strata (stratified proportional sampling). The selected sample of 32 students consisted of 18th grade IV students and 14th grade V students. The selected sample was divided into two groups: the experimental group 1 (K1) of 16 students and the experimental group 2 (K2) of 16 students.

Data collection techniques using the IAAF kid's athletics test instrument consisting of test items: (1) Canga's Escape in the form of a relay race with a combination of sprints and hurdles. (3) Turbo Throwing in the form of one-handed throwing to reach the distance with the javelin arrows and (4) Formula One in the form of a relay race with a combination of sprints, hurdles and slaloms (APPSO, 2011). Data analysis techniques through the stages of normality and homogeneity of data. Normality test to determine whether the data obtained is normally distributed or not, while the homogeneity test to determine whether the two samples taken have the same data variants or not using the F test analysis with significance level $\alpha=0.05$. After the data is declared normal and homogeneous, then to find out and prove the effect of the athletic training model the two groups of samples are analyzed using t-test statistical analysis on the significance level $(\alpha)=0.05$ (sig.0.05) and to test the difference in the two group means (independent sample ) using a one-way analysis of variance (anava) with significance level $(\alpha)$ $=0.05$ (sig.0.05).

\section{RESEARCH RESULT}

Analysis of the data in this study began with a normality test for the kids athletics test consisting of test items (1) Canga's Escape., (2) Frog Jump., (3) Turbo Throwing, (4) Formula One. The normality test results of the kids athletics instrument test group models of paired jump rope and ladder drill exercises are known to the Kolmogorov-Smirnov Two Tailed Test with real tarap $(\alpha=0.05)$ and degrees of freedom $(\mathrm{df}=15)$. Sig value $(0.05) \quad[p<\operatorname{Sig} 0.05]$ means that the distribution of data for each item of the kids athletics test for the pair jump rope and ladder drill exercises is normal. While the results of the homogeneity test group data model paired jump rope training and ladder drill known variant values (F) real tarap $(\alpha=0.05)$ and degrees of freedom (df) numerator and denominator (15; 15 ) it turns out that the F value calculated for each item of kids athletics test smaller than the value of $F(0.05)$ [ $\mathrm{F}<\mathrm{F} \mathrm{sig}$. 0.05$]$ means that the variant data for each item of the kids athletics test group models of paired jump rope and ladder drill exercises are declared homogeneous.

After the test data is declared normal and homogeneous, the next step is to test the hypothesis. This test aims to determine and membutikan increase in the ability of each element of kids athletics Elementary School students after participating in athletic training activities model jump rope pair and ladder drill. Hypothesis testing criteria used t-test statistical analysis. The results of the t-test analysis of the paired jump rope model group known the value of t-test with real tarap $(\alpha$ $=0.05)$ and degrees of freedom $(\mathrm{df}=15)$ it turns out that each element of kids athletics consisting of 1) Kanga's Escape of 1,900,2) Frog Jump of 3,203, 3) Turbo Throwing of 6,924 and 4) Formula One of 5,928 obtained values greater than 1,753 ( $\mathrm{t}$ count $>\mathrm{t}$ sig. 0.05 ), meaning that athletic training in pair jump rope shows a significant increase in each ability Element of Kids Athletics Elementary School Students. While the results of the calculation of the t-test ladder drill group known t-test value with real tarap $(\alpha=0.05)$ and degrees of freedom $(\mathrm{df}=15)$ it turns out that every element of kids athletics consisting of 1) Kanga's Escape of 6,305, 2) Frog Jump of 4,805, 3) Turbo Throwing of 5,917 and 4) Formula One of 5,209 obtained values greater than 1,753 ( $\mathrm{t}$ count $>\mathrm{t}$ sig. 0.05 ), meaning that the ladder drill model athletic training shows a significant increase in the ability of each element of kids elementary school athletics students.

The results of the difference in the influence of athletic training in pair jump rope models with ladder drill on the ability of each element of kids athletics and degrees of freedom $(\mathrm{df}=30)$ obtained the calculated $\mathrm{F}$ value consisting of 1) Kanga's Escape of 4,422, 2) Frog Jump of 2,522, 3) Turbo Throwing of 2,718 and 4) Formula One of 3,030 is known to the distribution value of $\mathrm{F}$ for each element of kids athletics in real tarap $(\alpha=$ $0.05)$ is greater than the value of 2.33 [Fh > F sig 0.05], meaning that there is a significant difference between athletic training in the jump model rope paired with a model of a ladder drill in improving the ability of the element athletics kids elementary school students.

\section{DISCUSSION}

Referring to the results of the analysis above, the results show that athletic training with a pair of jump 
rope models and ladder drill can improve the abilities of kids athletic elementary school students. The increase in ability is due to the effect of the training carried out systematically and programmed during the training. The effect of this exercise is a form of continuous treatment with gradually increasing intensity of exercise, because according to [7] physical exercise, especially if done regularly has been proven to increase physical abilities and endurance of the culprit. An increase in the ability of each element of athletic kids is caused by the effect when making vertical jump movements (jump rope) and horizontally (ladder drill) involving skeletal muscles (muscular skeleton), because when viewed from the characteristics of the basic motion of athletic kids is movements that include elements of running, jumping and throwing, because according to Wangeman, Elio, and Charles (2002), basic movements in kids athletics such as running, endurance, jumping, throwing can be done and trained in a form of play. In another part according to [1] kids' athletics is a game that has basic elements of running, jumping, throwing. The basic elements of running, jumping and throwing movements require the body's motor abilities in the form of force produced by the contraction of body muscles that can stimulate biomotor elements in the body which include strength, speed, agility, flexibility, power and endurance.

Based on the characteristics of children in childhood, it can be stated that the physical exercise approach that can be done is: (1) Physical activity aims to develop a multilateral physical nature. (2) Physical activity is oriented towards stimulating and stimulating children's growth and development. (3) Physical activity in the form of basic motion, which includes locomotor motion, stability and manipulative motion [1]. Therefore it can be said that the change in the ability level of the elements of athletic kids is the result of the training process in the form of playing jump rope training in pairs and ladder drill. Because according to Theodora. W (2013). jump rope game one of the games that can develop gross motor skills. Gross motor tasks, which include physical development in the form of coordination of body movements, such as running, standing on tiptoes, jumping, hanging, and maintaining balance. Meanwhile, according to Tsivkin (2011), ladder drill is an excellent form of athletic training to improve overall speed, coordination and leg agility. Kids athletics is a mirror of the basic abilities of athletic motion that can realize diverse athletic abilities in children so that they can develop multilateral motor skills in the form of running, jumping and throwing.

Whereas there is a difference in the increased ability of the elements of athletic kids produced between the athletic training of the pair jump rope model and the ladder drill model, this is caused by the characteristics of the pair jump rope movement model in the form of vertical jumping while the ladder drill model is horizontal jumping. The vertical jump movement in athletic training in the paired jump rope model will make children become more skilled at learning how to jump that requires their own skills, by frequently doing this game will make the child's muscles become strong, agile and trained [8]. The aspect of motion that is very dominant when making the jump rope to the vertical direction is a reflection of the child's motor skills in doing the basic movements of kids athletics. While the horizontal jump movement in the athletic training model ladder drills is the best and fun way to teach movement skills. Although the movements are linear and lateral when combined their movements will become complex. Therefore ladder drills or ladder exercises are the best and fun way to teach motion skills (Reynolds, 2011). According to [9], ladder drill can increase speed and agility ability. Besides ladder drill exercises affect running speed, agility and leg muscle strength. Referring to this concept, the element of motion in athletic training in the pair jump rope model and the ladder drill model has a different effect in increasing the child's motor skills. According to [10], there are three aspects in developing a child's motor skills, namely balance, body strength, and agility. From this opinion it can be concluded that the characteristics of jump rope movements produce more dominant motion on the physical condition elements such as strength, power, balance and endurance. While the characteristics of ladder drill movements produce more dominant motion on the physical condition elements such as speed, agility, leg muscle strength and leg muscle explosive power or the explosive power of the limbs.

Based on the above motion analysis, it can be concluded that there are differences in the results of athletic training in the pair jump rope and ladder drill models on the ability of athletic kids in elementary school students due to the more dominant training effect on horizontal than vertical movements. This is reinforced by the results of Primary, Mintarto and Kusnanik (2018) research, ladder drill training has a better effect than jump rope training in increasing speed and agility. While jumping rope exercises have a better effect than ladder drill exercises in increasing leg muscle strength. More dominant effect of ladder drill exercises compared to rope jumping exercises because the motion characteristics of ladder drill exercises have an effect on the leg muscles will continue to contract during exercise, so that it will produce a dominant physiological change in increasing the speed, strength and agility of children compared to jump rope training. According to Ghosh and [11] agility and balance are 
two factors that are interconnected and necessary for sports activities. Therefore, PJOK trainers and teachers are expected to be able to implement exercises to improve running speed, agility and strength of the leg muscles of students (Kusuma, 2017).

\section{CONCLUSION}

The conceptual research findings are two indicators, the pairing jump rope athletic training model and the ladder drill model both improve the ability of kids athletic students, but descriptively there is a difference in the improvement of kids athletic ability between athletic training in the pair jump rope model with the ladder drill model in school students Basic. From the three variables (X1, X2 and $\mathrm{Y})$ it can be concluded that, (1) The application of both athletic training models increases the ability of kids athletic students which include the elements of running, throwing and jumping. (2) The athletic training of the ladder drill model is better than the athletic training of the pair jump rope model on the ability of kids athletic elementary school students.

\section{REFERENCES}

[1] Rumini., 2014., Pembelajaran Permainan Kids' Atlhletics Sebagai Wujud Pengembangan Gerak Dasar Atletik Pada Anak-Anak, Journal of Physical Education, Health and Sport, FIK UNNES Semarang, 1 (2).

[2] Sari, Indah., 2015., Upaya Meningkatkan Kemampuan Motorik Kasar Anak Melalui Lompat Tali Berpasangan., Journal Student, FIS Universitas Negeri Yogyakarta. 1 (2).

[3] Febriani., E., 2016., Upaya Meningkatkan Pengembangan Motorik Kasar (Melompat) Anak Melalui Permainan Lompat Tali berpasangan, Jurnal FKIP., Universitas Sebelas Maret Surakarta 5 (2)

[4] Achmadi dan Luthfiyyatul Lailiyyah, 2018., Pengaruh Permainan Lompat Tali Terhadap Kemampuan Motorik Kasar Anak., Jurnal Wahana, LP2M Universitas PGRI Surabaya., (70) 1

[5] Bolton, B. 2016. Ladder and Functional Block Programing. Jurnal of Sports Science and Medicine: 2 (11)

[6] Sugiyono. 2013. Metode Penelitian Pendidikan Kualitatif dan Kualitatif,. Bandung. ALFABETA

[7] Harsono. 2015. Kepelatihan Atletik Olahraga, Teori dan Metodologi, Jakarta: Remaja Rodakarya.

[8] Kamtini dan Defita Kaban., 2016., Pengaruh Permainan Tradisional Lompat Tali Terhadap
Perkembangan Motorik Kasar., Jurnal Bunga Rampai Usia Emas, FIK Universitas Negeri Medan., 2 (1)

[9] Syahrulniza., 2015., Effect of Ladder DrillsTraining on Agility Performance. International Journal of Health. Physical Education and Computer Science In Sports, 17 (2)

[10] Nur Samsidar, 2014., Pengaruh Permainan Lompat Tali Terhadap Kemampuan Motorik Kasar Anak, Jurnal Bungapunti, FKIP Universitas Tadulako Sulawesi Tenggara. 2 (9)

[11] Ghosh, S.S. and Majumder, S. 2012. A Comparative Study on Agility and Dynamic Blence of Agility Football Volleyball and Hockey Players. Internasional Journal of Health, Physical Education and Computer Sciense in Sport. 8 (1) 